\title{
Analyzing vibration effect on amber buoying up velocity
}

\author{
Zynovii Malanchuk ${ }^{1 *}$, Valerii Korniienko ${ }^{1}$, Yevhenii Malanchuk $^{2}$, and Viktor Moshynskyi ${ }^{3}$ \\ ${ }^{1}$ National University of Water and Environmental Engineering, Department of Development of Deposits \\ and Mining, 11 Soborna St., 33028 Rivne, Ukraine \\ ${ }^{2}$ National University of Water and Environmental Engineering, Department of Automation, Electrical \\ Engineering and Computer-Integrated Technologies, 11 Soborna St., 33028 Rivne, Ukraine \\ ${ }^{3}$ National University of Water and Environmental Engineering, Department of Land Management, \\ Cadaster, Land Monitoring and Geoiformatics, 11 Soborna St., 33028 Rivne, Ukraine
}

\begin{abstract}
Industrial use of hydromechanical method and equipment made it possible to represent quantitative assessment of parameters for efficient amber extraction from amber-bearing deposits. Mined-out deposits with non-commercial reserves, being technogenic ones, may become potential source of amber mining; however, it should involve technological development. Due to imperfection of available methods, losses of the mineral in pillars and mine dumps excess $50 \%$. Taking into consideration positive vibration effect in the process of amber extraction from sandy deposits, special structure of vibration classifier has been designed making it possible to extract maximally even fine-size amber with the least technological losses. The studies have helped determine that the use of the vibration classifier to extract amber makes it possible to mine up to $95 \%$ of the mineral; in this context, both medium density and vibration effect amber-bearing sand dilution. Maximum velocity of amber buoying up achieves depending upon changes in water and air consumption for certain amber-bearing rock masses. Laboratory tests and full-scale experiments have determined that velocity values of amber buying up to the surface are $0.1 \mathrm{~m} / \mathrm{s}-0.21 \mathrm{~m} / \mathrm{s}$. The research has proved possibility of efficient use of integrated effect on rock mass of enhancing density of amber-bearing medium, vibration, and air flows in the form of bubbles. In this context, closed cycle on the liquid phase of the effect is implemented making it possible to substantiate the developed method for amber extraction.
\end{abstract}

\section{Introduction}

World demand for mineral resources experiences almost 5\% annual increase. Year over year, more than $100 \mathrm{bln}$ tons of minerals and fuel are extracted from the entrails of the Earth. Ukrainian mineral raw material base is one of the fullest in the world since it includes totality of minerals and components which can be applied in many industries [1 3]. Among other things, Ukrainian mineral raw material base is represented by a number of various minerals and sources of their extraction [4-10]. They are ores of ferrous and non-

\footnotetext{
*Corresponding author: malanchykzr@ukr.net
} 
ferrous metals, coal, oil, construction materials etc. [11, 12]. Moreover, significant amber reserves are concentrated in our state $[13,14]$.

Practices of hydromining method as for amber extraction are very limited taking into consideration huge differences in mining and geological characteristics of deposits, and enclosing rocks $[15,16]$. Basing upon the analysis of available methods of amber extraction, a new technique of amber mining from sandy deposits has been proposed. The hydromechanical technique provides more efficient extraction while mitigating negative environmental impact [13].

Industrial approbation of the new hydromechanical method and facilities has helped assess parameters for efficient amber extraction from amber-bearing deposits. Relying upon the carried-out geological analysis it has been determined that amber occurs in sandy soil and in sandy-argillaceous soil. Depth is shell - $1 \mathrm{~m}$ to $10-15 \mathrm{~m}$ [14].

Key tendency to develop the mining method and to improve it is the advance in borehole mechanical-hydraulic technique with the use of water, air, and vibration as the basic influence factors [17]. Mined-out deposits with non-commercial reserves, being technogenic ones, may become potential source of mining [15, 19]; however, it should involve technological development $[20,21]$. It is possible to substantiate regularities concerning distribution of minerals under the conditions of formation of such deposits which makes it possible to determine their location, and to identify parameters of the elevated concentration of minerals within technogenic deposits [22, 23].

Due to imperfection of available methods, losses of the mineral in pillars and mine dumps excess $50 \%$. The obtained research results point out the necessity of mining from technogenic waste (among which precious minerals are available) while determining their maximum concentration area according to the determined dependences for extracting and further processing [24-26]. It is possible to model such zones of mineral concentration for their adequate classification $[27,28]$.

Available methods of amber extraction from sandy and sandy-argillaceous rocks are very energy-intensive as for rock breaking and segregation needs perfection of technology, and equipment to improve the efficiency of end product extraction, and reduced power, water, and air consumption. The proposed operation schedules [29-33] do not involve environmental component, and possibility to reclaim mining wastes when their technogenic nature needs additional studies taking into consideration different mining and geological characteristics and enclosing rocks as well as development of recommendations concerning both methods and equipment involving environmental component.

Objective of the research was to analyze medium density effect and vibratory excitation effect in the context of hydromechanical amber extraction with the determination of the operating procedure parameters and analysis of the operating medium characteristics.

\section{Methodology}

The prediction of the producing wells stability in the technology of underground coal gasification is supposed to be made in mines that develop thin and very thin coal seams. The enterprises are preferable that develop the seams with low thickness in difficult mining and geological conditions. In terms of location, the coal reserves are available in the Donetsk and Lviv-Volyn coal basins.

Taking into consideration positive effect of vibration in the process of amber extraction method implementation in the context of sandy deposits, special structure of vibration classifier has been designed making it possible to extract maximally even fine-size amber with the least technological losses [34, 35]. Further studies made it possible to upgrade spiral classifier up to the configuration when integrated action of vibration, and water and air supply is used intensifying a process of amber fractions buoying up [36, 37]. 
Vibration classifier (Fig. 1) consists of a base 1 on which casing 3 with vibration exciter 4 is mounted with the help of spring elements 2 ; screw 5 ; drive 7; support 6 ; mechanism to lift lower parts of the screw 8 ; slurry; loading device 10; unloading device 11; blade extractors for mineral; vibration exciters 13; and intake drainage trench 14.

The vibration classifier operates as follows. With the help of loading device 10, material in the form of slurry is supplied to a cavity shaped by a casing 3 where it is blended under the action of screw 5 and vibration exciter 4. During the blending, the heaviest and largest material classes are deposited and leave the classifier through unloading device 11 in the form of sand owing to screw 5 , being rotated by means of a drive 6 . In this context, the material is both unloaded and dried; operation by vibration exciter 4 favours the process. There is also possibility to vary inclination angle of the screw since it is mounted on support 7 and regulated by a lifting mechanism 8 . The material parts, which density is less than density of slurry, buoy up to the surface under the action of screw 5 , and vibration exciter 4 . There, being acted by both vertical component and horizontal component of vibration exciters 4 , they are taken off by means of blade catchers, and supplied to intake drainage trench 14 . To intensify the process of fraction buoying up, air is supplied to slurry using air piping 15 . Unloading device 11 is required to control slurry density providing medium providing medium to classify material.

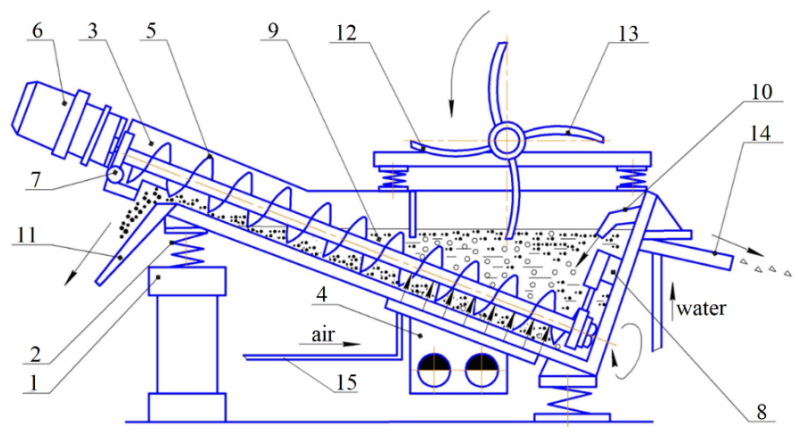

Fig. 1. Vibration classifier with blade extractors for the mineral.

The following was observed while analyzing effect of vibration parameters on the medium density:

- amber buoying up velocity has its maximum, and depends upon vibration frequency, amplitude, and medium density;

- there are certain medium densities in terms of which maximum amber buoying up velocity is maximum depending on vibration frequency, and water and air supply;

- medium density varies significantly amber buoying up velocity also effecting the efficiency of amber mining facilities; and

- there are such values of vibration parameters, and air and water supply parameters, in terms of which suspense medium is not generated; thus, amber buoying is not available.

It is possible to intensify the process while combining vibration, and water, or water and air supply to the rock mass [38 - 40] as well as was shown during filtration modelling [41 - 44], application ignition, optical and concrete composition [45 - 48].

\section{Results and discussion}

Basing upon experimental data, concerning amber fractions with $m=15-20 \mathrm{~g}$ weight, graphic dependences of medium density $\left(\rho_{c}\right)$ (Fig. 2, Table 1), amber buoying up velocities $(V)$ (Fig. 3, Table 2) and amplitudes of intensification means $(A)$ (Fig. 4, Table 3) on vibration frequency $(\omega)$ have been obtained during experiments involving vibration classifier. 
Table 1. Dependence of medium density on vibration frequency.

\begin{tabular}{|c|c|c|c|c|c|c|}
\hline$\omega, \mathrm{rpm}$ & 1100 & 1300 & 1500 & 1700 & 1900 & 2100 \\
\hline$\rho_{c}{ }^{1}, \mathrm{~kg} / \mathrm{m}^{3}$ & 1995 & 1855 & 1735 & 1688 & 1682 & 1705 \\
\hline$\rho_{c}{ }^{2}, \mathrm{~kg} / \mathrm{m}^{3}$ & 2000 & 1990 & 1870 & 1700 & 1550 & 1660 \\
\hline$\rho_{c}{ }^{3}, \mathrm{~kg} / \mathrm{m}^{3}$ & 2100 & 2000 & 1770 & 1750 & 1700 & 1660 \\
\hline
\end{tabular}

In Table $1 \rho_{c}{ }^{1}$ is variation of medium density by means of water and air supply to the rock mass; $\rho_{c}{ }^{2}$ is variation of medium density with no water and air supply to the rock mass; and $\rho_{c}{ }^{3}$ is variation of medium density with no water and air supply to the rock mass.

According to the experiment results, dependences of medium density $\left(\rho_{c}\right)$ upon vibration frequency $(\omega)$ are approximated using following expressions:

- for $\rho_{c}{ }^{1}=22.696 \omega^{2}-216.47 \omega+2190.1$ medium density with $R^{2}=0.9973$ value of approximation reliability;

- for $\rho_{c}^{2}=8.5714 \omega^{2}-151.14 \omega+2194$ medium density with $R^{2}=0.8564$ value of approximation reliability;

- for $\rho_{c}^{3}=18.14 \omega^{2}-216.64 \omega+2312$ medium density with $R^{2}=0.961$ value of approximation reliability.

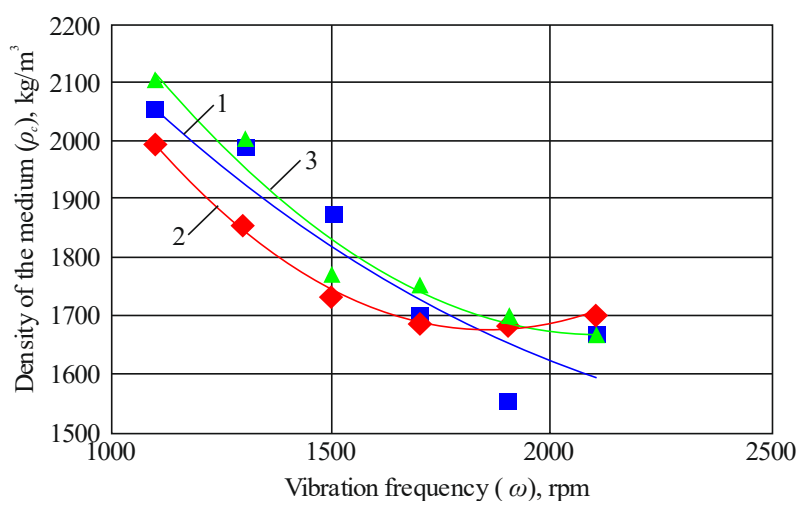

Fig. 2. Dependence of the density of the medium on the vibration frequency: 1 - no water and air; 2 - water and air supply; 3 - air and no water.

Table 2. Dependence of amber buoying up velocity $(V)$ on vibration frequency $(\omega)$.

\begin{tabular}{|c|c|c|c|c|c|c|}
\hline$\omega, \mathrm{rpm}$ & 1100 & 1350 & 1450 & 1550 & 1700 & 2100 \\
\hline$V_{1}, \mathrm{~m} / \mathrm{s}$ & 0.045 & 0.145 & 0.148 & 0.132 & 0.13 & 0.117 \\
\hline$V_{2}, \mathrm{~m} / \mathrm{s}$ & 0.041 & 0.199 & 0.185 & 0.109 & 0.086 & 0.055 \\
\hline$V_{3}, \mathrm{~m} / \mathrm{s}$ & 0.037 & 0.183 & 0.092 & 0.086 & 0.062 & 0.033 \\
\hline$V_{4}, \mathrm{~m} / \mathrm{s}$ & 0.033 & 0.167 & 0.169 & 0.063 & 0.038 & 0.011 \\
\hline$V_{5}, \mathrm{~m} / \mathrm{s}$ & 0.029 & 0.051 & 0.146 & 0.04 & 0.014 & 0.005 \\
\hline$V_{6}, \mathrm{~m} / \mathrm{s}$ & 0.025 & 0.035 & 0.023 & 0.017 & 0.01 & 0.0005 \\
\hline
\end{tabular}

In Table $2 V_{1}$ is air consumption $q_{a}=0.0055 \mathrm{~m}^{3} /$ hour; $V_{2}$ is air consumption $q_{a}=0.0025 \mathrm{~m}^{3} /$ hour; $V_{3}$ is air consumption $q_{a}=0.0035 \mathrm{~m}^{3} /$ hour; $V_{4}$ is air consumption $q_{a}=0.0045 \mathrm{~m}^{3} /$ hour; $V_{5}$ is air consumption $q_{a}=0.0065 \mathrm{~m}^{3} /$ hour; $V_{6}$ is air consumption $q_{a}=0.0070 \mathrm{~m}^{3} /$ hour.

Table 3. Dependence of amplitude $(A)$ on vibration frequency $(\omega)$.

\begin{tabular}{|l|l|l|l|l|l|l|}
\hline$\omega, \mathrm{rpm}$ & 1100 & 1300 & 1500 & 1700 & 1900 & 2100 \\
\hline$A, \mathrm{~mm}$ & 1.51 & 2.75 & 2.45 & 2.32 & 1.91 & 2.05 \\
\hline
\end{tabular}




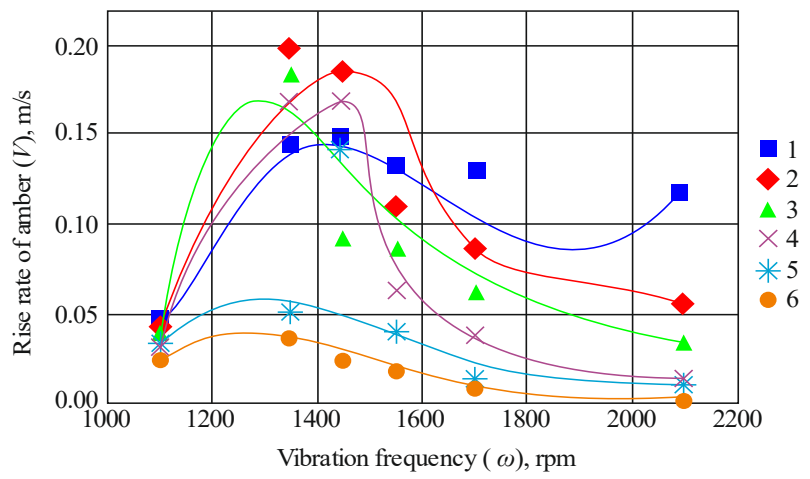

Fig. 3. Dependence of amber buoying up velocity on vibration frequency if: $1-q_{a}=0.0055 \mathrm{~m}^{3} /$ hour; $2-q_{a}=0.0025 \mathrm{~m}^{3} /$ hour; $3-q_{a}=0.0035 \mathrm{~m}^{3} /$ hour; $4-q_{a}=0.0045 \mathrm{~m}^{3} /$ hour; $5-q_{a}=0.0065 \mathrm{~m}^{3} /$ hour; $6-q_{a}=0.0070 \mathrm{~m}^{3} /$ hour.

In accordance with the experiment results, dependences of amber buoying up velocity $(V)$ on vibration frequency $(\omega)$ are approximated as follows:

$-V_{1}=7 \cdot 10^{-10} \omega^{3}-4 \cdot 10^{-6} \omega^{2}+0.0063 \omega-3.2883$ for amber buoying up velocity where approximation reliability is $R^{2}=0.9777$;

$-V_{2}=2 \cdot 10^{-9} \omega^{3}-1 \cdot 10^{-5} \omega^{2}+0.0153 \omega-7.781$ for amber buoying up velocity where approximation reliability is $R^{2}=0.9336$;

$-V_{3}=1 \cdot 10^{-9} \omega^{3}-7 \cdot 10^{-6} \omega^{2}+0.0116 \omega-5.8309$ for amber buoying up velocity where approximation reliability is $R^{2}=0.7602$;

$-V_{4}=2 \cdot 10^{-9} \omega^{3}-1 \cdot 10^{-5} \omega^{2}+0.0161 \omega-8.0969$ for amber buoying up velocity where approximation reliability is $R^{2}=0.9036$;

$V_{6}=2 \cdot 10^{-10} \omega^{3}-1 \cdot 10^{-6} \omega^{2}+0.0016 \omega-0.7472$ for amber buoying up velocity where approximation reliability is $R^{2}=0.9501$.

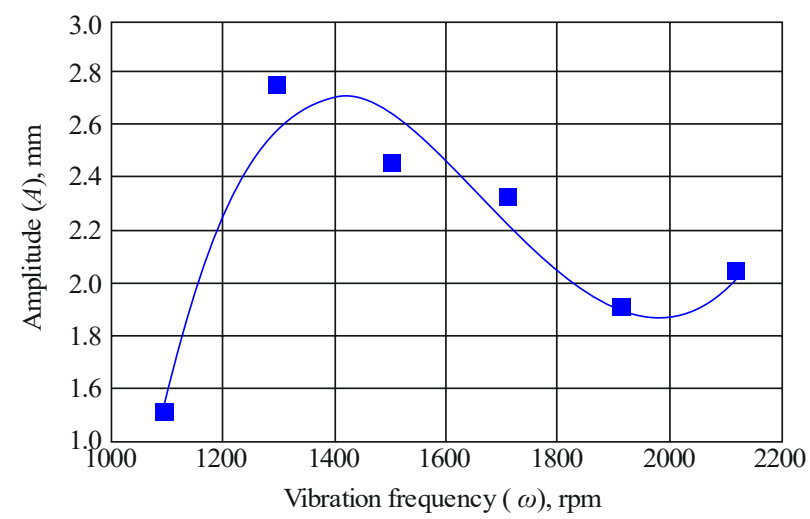

Fig. 4. Dependence of amplitude $(A)$ on vibration frequency $(\omega)$.

According to the experiment results, dependence of amplitude of intensification facilities $(A)$ upon vibration frequency $(\omega)$ is approximated in such a way:

- for amplitude of intensifier $(A): A=1 \cdot 10^{-8} \omega^{3}-5 \cdot 10^{-5} \omega^{2}+0.0873 \omega-44.062$ where approximation reliability is $R^{2}=0.9218$.

The carried-out studies have determined $\left(\rho_{c}=1650-1850 \mathrm{~kg} / \mathrm{m}^{3}\right)$ medium density which is achieved if oscillation frequency is $22.5-28 \mathrm{~Hz}$, amplitude $A=1.51-2.75 \mathrm{~mm}$, air supply $q_{a}=0.0025-0.0055 \mathrm{~m}^{3} /$ hour when amber buoying up velocity is $V=0.11-0.199 \mathrm{~m} / \mathrm{s}$. 
Moreover, the experiments have helped identify dependences, and supported regularities of the effect of vibration parameters of hydromechanical method for amber extraction from amber-bearing deposits; medium density, amplitude, and vibration frequency are the basic parameters effecting the intensity of amber buoying up velocity.

Vibration classifier (Fig. 1) was applied to study effect of vibration as well as air and water supply on the amber buoying up velocity to determine basic factors of the process

To determine buoying up velocity of different amber fractions, amber-bearing rock mass experienced action of vibration; water and air were supplied. Experimental values have been obtained for different operation modes of the device: with vibration action and without it; with water supply and without air supply; and with air supply and without water supply. Table 4 demonstrates the data.

Table 4. Experimental data of buoying up velocity of different amber fractions in the context of different operation modes.

\begin{tabular}{|c|c|c|c|c|c|}
\hline \multirow{2}{*}{$\begin{array}{c}\text { Amber } \\
\text { mass } m, \mathrm{~g}\end{array}$} & $\begin{array}{c}\text { Vibration } \\
\text { with water } \\
\text { and air }\end{array}$ & $\begin{array}{c}\text { Vibration with } \\
\text { water and } \\
\text { without air }\end{array}$ & $\begin{array}{c}\text { Vibration } \\
\text { without water } \\
\text { and air }\end{array}$ & $\begin{array}{c}\text { Without } \\
\text { vibration, with } \\
\text { water and air }\end{array}$ & $\begin{array}{c}\text { Without } \\
\text { vibration, with } \\
\text { water, and } \\
\text { without air }\end{array}$ \\
\hline$\sim 15$ & 0.10 & 0.05 & 0.001 & 0.05 & 0.0011 \\
\hline$\sim 20$ & 0.12 & 0.08 & 0.0012 & 0.08 & 0.0014 \\
\hline$\sim 25$ & 0.13 & 0.09 & 0.0014 & 0.085 & 0.0018 \\
\hline$\sim 30$ & 0.13 & 0.11 & 0.0022 & 0.09 & 0.0029 \\
\hline$\sim 35$ & 0.14 & 0.15 & 0.008 & 0.10 & 0.01 \\
\hline$\sim 40$ & 0.15 & 0.18 & 0.009 & 0.11 & 0.011 \\
\hline$\sim 45$ & 0.20 & 0.19 & 0.01 & 0.12 & 0.012 \\
\hline$\sim 50$ & 0.21 & 0.2 & 0.015 & 0.14 & 0.017 \\
\hline$\sim 55$ & 0.24 & 0.21 & 0.021 & 0.14 & 0.023 \\
\hline$\sim 60$ & 0.28 & 0.22 & 0.022 & 0.15 & 0.024 \\
\hline$\sim 65$ & 0.30 & 0.24 & 0.023 & 0.16 & 0.025 \\
\hline$\sim 70$ & 0.33 & 0.25 & 0.022 & 0.17 & 0.027 \\
\hline
\end{tabular}

Basing upon the experimental data, graphic dependences of amber buoying up velocity $(V)$ on the weight amber fraction $(m)$ were obtained in the context of different operation modes of the device (Fig. 5).

According to the results of the experiment, the dependence of the rising rate of amber $(V)$ on the mass fraction of amber $(m)$ under different operation modes of the installation, are approximated by the following expressions:

- for buoying up velocity if vibration action with water and air is available $V=-7 \cdot 10^{-05}$ $m^{3}+0.0028 m^{2}-0.0053 m+0.1114$ with $R^{2}=0.9877$ value of approximation reliability;

- for buoying up velocity if vibration action with water and air is available $V=-2 \cdot 10^{-05}$ $m^{3}+0.0006 m^{2}-0.0286 m+0.0198$ with $R^{2}=0.9863$ value of approximation reliability;

- for buoying up velocity if vibration action with water and air is available $V=-4 \cdot 10^{-05}$ $m^{3}+0.0008 m^{2}-0.0157 m+0.0416$ with $R^{2}=0.9822$ value of approximation reliability;

- for buoying up velocity if vibration action with water and air is available $V=-4 \cdot 10^{-05}$ $m^{3}+0.0009 m^{2}-0.0124 m+0.0027$ with $R^{2}=0.9816$ value of approximation reliability;

- for buoying up velocity if vibration action with water and air is available $V=-4 \cdot 10^{-05}$ $m^{3}+0.0009 m^{2}-0.0024 m+0.0027$ with $R^{2}=0.9816$ value of approximation reliability.

Graphic dependences (Fig. 5) help conclude that it is possible to intensify amber extraction process while combining vibration, water supply to the rock mass, of water and air consumption. 
The experiments determined maximum velocity (i.e. $V=0.33 \mathrm{~m} / \mathrm{s}$ ) achieved for $m=70 \mathrm{~g}$ amber fractions under the action of vibration with water and air supply.

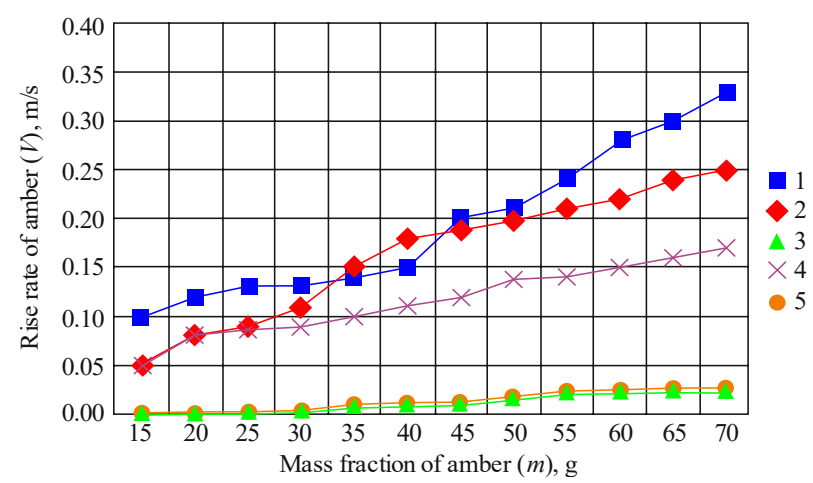

Fig. 5. Graphic dependences of various amber fraction buoying up velocity in the context of different operation modes of the device: 1 - vibration with water and air; 2 - vibration with water and without air; 3 - water-and airless vibration; 4 - water-and airless vibration; 5 - without vibration, with water and without air.

As for the smallest (i.e. $m=15 \mathrm{~g}$ ) fractions, maximum velocity, being $V=0.1 \mathrm{~m} / \mathrm{s}$ is achieved if vibration is combined with water and air.

The studies also determined dependences of vibration action, and water and air supply on amber buoying up velocity in the context of hydromechanical method of amber extraction from amber-bearing deposits making it possible to mine the smallest amber fractions and vibration action, and water and air supply are the basic parameters, effecting the intensity of amber buoying up to the surface.

The studies, concerning amber extraction from sandy amber-bearing rock masses, identified the following:

- amber extraction velocity depends upon vibration frequency, amplitude, and medium density; moreover, it has its optimum;

- optimum values of water and air supply, under which maximum amber buoying velocity is achieved, are available in terms of different vibration frequency values; and

- medium density effects significantly the development of fast amber buoying up to the slurry surface of vibration classifier.

The experiments have determined medium density, being $\rho_{c}=1790-1875 \mathrm{~kg} / \mathrm{m}^{3}$, with $20-30 \mathrm{~Hz}$ oscillation frequency, $A=1.5-2.55 \mathrm{~mm}$ amplitude, and $q_{n}=0.0025-$ $0.0055 \mathrm{~m}^{3} / \mathrm{h}$ air supply when amber buoying up velocity is $0.1 \mathrm{~m} / \mathrm{s}-0.21 \mathrm{~m} / \mathrm{s}$.

\section{Conclusions}

The experiments, concerning vibration effect on the amber buoying up velocity, have determined that:

- the use of vibration classifier makes it possible to extract up to $95 \%$ of amber from deposit; in this context, medium density as well as vibration effects amber-bearing sand dilution;

- maximum velocity of amber buoying up velocity is achieved depending upon changes in water and air consumption depending upon certain amber-bearing rock masses; in this context, $0.1 \mathrm{~m} / \mathrm{s}$ to $0.21 \mathrm{~m} / \mathrm{s}$ amber buoying up velocity values have been identified; and

- operation schedule of hydromechanical method for amber extraction has been improved; possibility to use efficiently the integrated effect on higher density amber-bearing rock mass, 
vibration, and air flows in the form of bubbles. In this context, closed cycle of amber extraction from amber-bearing sands is implemented making it possible to develop both process procedure and specifications concerning industrial extraction of amber.

We would like to express our gratitude to Bortnik Petro Petrovych, director of the private joint-stock company "Rafalivskyi Quarry", for his assistance in the organization of research works. The results were obtained without financial support.

\section{References}

1. Medunić, G., Mondol, D., Rađenović, A., \& Nazir, S. (2018). Review of the latest research on coal, environment, and clean technologies. Rudarsko Geolosko Naftni Zbornik, 33(3), 13-21. https://doi.org/10.17794/rgn.2018.3.2

2. Lozynskyi, V., Saik, P., Petlovanyi, M., Sai, K., Malanchuk, Z. \& Malanchuk, Y. (2018). Substantiation into mass and heat balance for underground coal gasification in faulting zones. Inzynieria Mineralna, 19(2), 289-300. https://doi.org/10.29227/IM-2018-02-36

3. Nosić, A., Karasalihović Sedlar, D., \& Jukić, L. (2017). Oil and gas futures and options market. Rudarsko Geolosko Naftni Zbornik, 32(4), 45-54. https://doi.org/10.17794/rgn.2017.4.5

4. Petlovanyi, M.V., Lozynskyi, V.H., Saik, P.B., \& Sai, K.S. (2018). Modern experience of lowcoal seams underground mining in Ukraine. International Journal of Mining Science and Technology, 28(6), 917-923. https://doi.org/10.1016/j.ijmst.2018.05.014

5. Bondarenko, V. (2015). An overview and prospectives of practical application of the biomass gasification technology in Ukraine. New Developments in Mining Engineering 2015: Theoretical and Practical Solutions of Mineral Resources Mining, 27-32. https://doi.org/10.1201/b19901-6

6. Stupnik, M., \& Kalinichenko, V. (2013). Magnetite quartzite mining is the future of Kryvyi Rig iron ore basin. Annual Scientific-Technical Collection - Mining of Mineral Deposits 2013, 49-52. https://doi.org/10.1201/b16354-10

7. Kalinichenko, V., Pysmennyi, S., Shvaher, N., \& Kalinichenko, O. (2018). Selective underground mining of complex structured ore bodies of Kryvyi Rih Iron Ore Basin. E3S Web of Conferences, (60), 00041. https://doi.org/10.1051/e3sconf/20186000041

8. Stupnik, M. (2019). Investigation of the dust formation process when hoisting the uranium ores with a bucket. Mining of Mineral Deposits, 13(3). Article in press.

9. Stupnik, M., Kolosov, V., Kalinichenko, V., \& Pismennyi, S. (2014). Physical modeling of waste inclusions stability during mining of complex structured deposits. Progressive Technologies of Coal, Coalbed Methane, and Ores Mining, 25-30. https://doi.org/10.1201/b17547-6

10. Stupnik, M. I., Kalinichenko, V. O., Pysmennyi, S. V., \& Kalinichenko, O. V. (2018). Determining the qualitative composition of the equivalent material for simulation of Kryvyi Rih iron ore basin rocks. Naukovyi Visnyk Natsionalnoho Hirnychoho Universytetu, (4), 21-27. https://doi.org/10.29202/nvngu/2018-4/4

11. Petlovanyi, M., Kuzmenko, O., Lozynskyi, V., Popovych, V., Sai, K., \& Saik, P. (2019). Review of man-made mineral formations accumulation and prospects of their developing in mining industrial regions in Ukraine. Mining of Mineral Deposits, 13(1), 24-38. https://doi.org/10.33271/mining13.01.024

12. Law, B.E., Ulmishek, G.F., Clayton, J.L., Kabyshev, B.P., Pashova, N.T., \& Krivosheya, V.A. (1998). Basin-centered gas evaluated in Dnieper-Donets basin, Donbas foldbelt, Ukraine. Oil and Gas Journal, 96(47), 74-78.

13. Malanchuk, Z., Korniyenko, V., Malanchuk, Y., \& Khrystyuk, A. (2016). Results of experimental studies of amber extraction by hydromechanical method in Ukraine. Eastern-European Journal of Enterprise Technologies, 3(10(81)), 24. https://doi.org/10.15587/17294061.2016.72404

14. Malanchuk, Z., Moshynskyi, V., Malanchuk, Y., \& Korniienko, V. (2018). Physico-Mechanical and Chemical Characteristics of Amber. Solid State Phenomena, (277), 80-89. https://doi.org/10.4028/www.scientific.net/ssp.277.80 
15. Lozynskyi, V., Dychkovskyi, R., Saik, P., \& Falshtynskyi, V. (2018). Coal Seam Gasification in Faulting Zones (Heat and Mass Balance Study). Solid State Phenomena, (277), 66-79. https://doi.org/10.4028/www.scientific.net/SSP.277.66

16. Gornostayev, S.S., Crocket, J.H., Mochalov, A.G., \& Laajoki, K.V.O. (1999). The platinumgroup minerals of the Baimka placer deposits, Aluchin horst, Russian Far East. Canadian Mineralogist, 37(5), 1117-1129.

17. Malanchuk, Ye., Korniienko, V., Moshynskyi, V., Soroka, V., Khrystyuk, A., \& Malanchuk, Z. (2019). Regularities of hydromechanical amber extraction from sandy deposits. Mining of Mineral Deposits, 13(1), 49-57. https://doi.org/10.33271/mining13.01.049

18. Kalybekov, T., Rysbekov, K.B., Toktarov, A.A., Otarbaev, O.M. (2019). Underground mine planning with regard to preparedness of mineral reserves. Mining Informational and Analytical Bulletin, (5), 34-43.

19. Rysbekov, K., Huayang, D., Kalybekov, T., Sandybekov, M., Idrissov, K., Zhakypbek, Y., Bakhmagambetova, G. (2019). Application features of the surface laser scanning technology when solving the main tasks of surveying support for reclamation. Mining of Mineral Deposits, 13(3), 40-48. https://doi.org/10.33271/mining13.03.040

20. Cherniaiev, O.V. (2017). Systematization of the hard rock non-metallic mineral deposits for improvement of their mining technologies. Naukovyi Visnyk Natsionalnoho Hirnychoho Universytetu, (5), 11-17.

21. Bazaluk, O., \& Matusevych, T. (2014). Otto friedrich bollnow: Search for the fundamentals of existential philosophy. Analele Universitatii din Craiova. Seria Filozofie, 34(2), 5-16.

22. Naduty, V., Malanchuk, Z., Malanchuk, Y., \& Korniyenko, V. (2016). Research results proving the dependence of the copper concentrate amount recovered from basalt raw material on the electric separator field intensity. Eastern-European Journal of Enterprise Technologies, 5(5(83)), 19-24. https://doi.org/10.15587/17294061.2016.79524

23. Kalybekov, T., Rysbekov, K., \& Zhakypbek, Y. (2015). Efficient land use in open-cut mining. New Developments in Mining Engineering 2015: Theoretical and Practical Solutions of Mineral Resources Mining, 287-291. https://doi.org/10.1201/b19901-51

24. Kuttykadamov, M.E., Rysbekov, K.B., Milev, I., Ystykul, K.A., \& Bektur, B.K. (2016). Geodetic monitoring methods of high-rise constructions deformations with modern technologies application. Journal of Theoretical and Applied Information Technology, 93(1), 24-31.

25. Aitkazinova, S., Soltabaeva, S., Kyrgizbaeva, G., Rysbekov, K., \& Nurpeisova, M. (2016). Methodology of assessment and prediction of critical condition of natural-technical systems. International Multidisciplinary Scientific GeoConference Surveying Geology and Mining Ecology Management, SGEM 2, 3-10. https://doi.org/10.5593/sgem2016/b22/s09.001

26. Malanchuk, Z., Malanchuk, Y., Korniyenko, V., \& Ignatyuk, I. (2017). Examining features of the process of heavy metals distribution in technogenic placers at hydraulic mining. EasternEuropean Journal of Enterprise Technologies, 1(10(85)), 45-51. https://doi.org/10.15587/17294061.2017.92638

27. Naduty, V., Malanchuk, Z., Malanchuk, E., Korniyenko, V. (2015). Modeling of vibro screening at fine classification of metallic basalt. New Developments in Mining Engineering 2015: Theoretical and Practical Solutions of Mineral Resources Mining, 441-444. https://doi.org/10.1201/b19901-77

28. Bondarenko, V., Maksymova, E., \& Koval, O. (2013). Genetic classification of gas hydrates deposits types by geologic-structural criteria. Annual Scientific-Technical Collection - Mining of Mineral Deposits 2013, 115-119. https://doi.org/10.1201/b16354-21

29. Khomenko, O.Ye., Sudakov, A.K., Malanchuk, Z.R., \& Malanchuk, Ye.Z. (2017). Principles of rock pressure energy usage during underground mining of deposits. Naukovyi Visnyk Natsionalnoho Hirnychoho Universytetu, (2), 34-43.

30. Malanchuk, Z., Malanchuk, Ye., \& Khrystiuk, A. (2016). Mathematical modeling of hydraulic mining from placer deposits of minerals. Mining of Mineral Deposits, 10(2), 18-24. https://doi.org/10.15407/mining10.02.018

31. Malanchuk, Z., Korniienko, V., Malanchuk, Ye., Soroka, V., \& Vasylchuk, O. (2018). Modeling 
the formation of high metal concentration zones in man-made deposits. Mining of Mineral Deposits, 12(2), 76-84. https://doi.org/10.15407/mining12.02.076

32. Lozynskyi, V., Saik, P., Petlovanyi, M., Sai, K., \& Malanchyk, Ye. (2018). Analytical Research of the Stress-Deformed State in the Rock Massif Around Faulting. International Journal of $\begin{array}{lllll}\text { Engineering } \quad \text { Research } & \text { in }\end{array}$ https://doi.org/10.4028/www.scientific.net/JERA.35.77b

33. Dychkovskyi, R.O., Lozynskyi, V.H., Saik, P.B., Petlovanyi, M.V., Malanchuk, Ye.Z., \& Malanchuk, Z.R. (2018). Modeling of the disjunctive geological fault influence on the exploitation wells stability during underground coal gasification. Archives of Civil and Mechanical Engineering, 18(4). https://doi.org/10.1016/j.acme.2018.01.012

34. Malanchuk, Z., Korniienko, V., \& Malanchuk, Ye. (2017). Results of research into amber mining by hydromechanical method. Mining of Mineral Deposits, 11(1), 93-99. https://doi.org/10.15407/mining11.01.093

35. Malanchuk, E., Malanchuk, Z., Korniienko, V., \& Gromachenko, S. (2016). The results of magnetic separation use in ore processing of metalliferous raw basalt of Volyn region. Mining of Mineral Deposits, 10(3), 77-83. http://dx.doi.org/10.15407/mining10.03.077

36. Mikhlin, Y. V., \& Zhupiev, A. L. (1997). An application of the ince algebraization to the stability of non-linear normal vibration modes. International Journal of Non-Linear Mechanics, 32(2), 393-409. https://doi.org/10.1016/s0020-7462(96)00047-9

37. Beshta, O.S. (2012). Electric drives adjustment for improvement of energy efficiency of technological processes. Naukovyi Visnyk Natsionalnoho Hirnychoho Universytetu, (4), 98-107.

38. Malanchuk, Y., Moshynskyi, V., Korniienko, V., \& Malanchuk, Z. (2018). Modeling the process of hydromechanical amber extraction. E3S Web of Conferences, (60), 00005. https://doi.org/10.1051/e3sconf/20186000005

39. Saik, P.B., Dychkovskyi, R.O., Lozynskyi, V.H., Malanchuk, Z.R., \& Malanchuk, Ye.Z. (2016). Revisiting the underground gasification of coal reserves from contiguous seams. Naukovyi Visnyk Natsionalnoho Hirnychoho Universytetu, (6), 60-66.

40. Lozynskyi, V.G., Dychkovskyi, R.O., Falshtynskyi, V.S., Saik, P.B., \& Malanchuk, Ye.Z. (2016). Experimental study of the influence of crossing the disjunctive geological fault on thermal regime of underground gasifier. Naukovyi Visnyk Natsionalnoho Hirnychoho Universytetu, (5), 21-29.

41. Chui, Y.V., Moshynskyi, V.S., Martyniuk, P.M., \& Stepanchenko, O.M. (2018). On conjugation conditions in the filtration problems upon existence of semipermeable inclusions. JP Journal of Heat and Mass Transfer, 15(3), 609-619.

42. Kuzlo, M.T., Moshynskyi, V.S., Martyniuk, P.M. (2018). Mathematical modelling of soil massif's deformations under its drainage. International Journal of Applied Mathematics, 31(6), 751-762.

43. Bomba, A., Tkachuk, M., Havryliuk, V., Kyrysha, R., Gerasimov, I., \& Pinchuk, O. (2018). Mathematical modelling of filtration processes in drainage systems using conformal mapping. Journal of Water and Land Development, 39(1), 11-15. https://doi.org/10.2478/jwld-2018-0054

44. Malanchuk, Z.R. (2019). Substantiating parameters of zeolite-smectite puff-stone washout and migration within an extraction chamber. Naukovyi Visnyk Natsionalnoho Hirnychoho Universytetu, (6), Article in press.

45. Chernai, A.V., Sobolev, V.V., Chernai, V.A., Ilyushin, M.A., \& Dlugashek, A. (2003). Laser ignition of explosive compositions based on di-(3-hydrazino-4-amino-1,2,3-triazole)-copper(II) perchlorate. Combustion, Explosion and Shock Waves, 39(3), 335-339.

46. Sobolev, V.V., \& Usherenko, S.M. (2006). Shock-wave initiation of nuclear transmutation of chemical elements. Journal de Physique IV (Proceedings), (134), 977-982.

47. Ozga, K., Michel, J., Nechyporuk, B.D., Ebothé, J., Kityk, I.V., Albassam, A.A., \& Fedorchuk, O. (2016). ZnS/PVA nanocomposites for nonlinear optical applications. Physica E: LowDimensional Systems and Nanostructures, (81), 281-289. https://doi.org/10.1016/j.physe.2016.03.041

48. Dvorkin, L., Dvorkin, O., Zhitkovsky, V., \& Ribakov, Y. (2011). A method for optimal design of steel fiber reinforced concrete composition. Materials \& Design, 32(6), 3254-3262. https://doi.org/10.1016/j.matdes.2011.02.036 